\title{
Zinc accumulation in phosphate granules of Ucides cordatus hepatopancreas
}

\section{J.D. Corrêa Junior ${ }^{1}$, S. Allodi2, \\ G.M. Amado-Filho ${ }^{3}$ and M. Farina ${ }^{1}$}

\author{
Departamentos de ${ }^{1}$ Anatomia and ${ }^{2} \mathrm{H}$ istologia e Embriologia, \\ Centro de Ciências da Saúde, Universidade Federal do Rio de Janeiro, \\ Rio de Janeiro, RJ, Brasil \\ 3Programa Zona Costeira, Instituto de Pesquisas Jardim Botânico, \\ Ministério do Meio Ambiente, Rio de Janeiro, RJ, Brasil
}

\section{Correspondence \\ M. Farina \\ Laboratório de Biomineralização \\ Departamento de Anatomia, CCS, \\ UFRJ \\ 21941-590 Rio de Janeiro, RJ \\ Brasil \\ Fax: + 55-21-280-8193 \\ E-mail: mfarina@ anato.ufrj.br}

Research supported by PRO NEX, FAPERJ, Fundação Universitária José Bonifácio (FUJB), and the Third W orld Academy of Sciences (TW AS). J.D. Corrêa Junior is the recipient of a post-graduate research fellowship from $\mathrm{CNPq}$.

Received June 7, 1999 Accepted November 18, 1999

\section{Abstract}

Amorphous phosphate granules are present in vertebrate and invertebrate organisms. The functions attributed to these structures depend on their mineral contents and organic matrix composition. In the present study we have determined zinc concentrations in the hepatopancreas of the crab Ucides cordatus from regions contaminated with zinc, and the elemental composition of hepatopancreal phosphate granules. Organisms were collected from the contaminated areas of Sepetiba Bay (SB) and Guanabara Bay (GB), and from a non-contaminated area, Ribeira Bay (RB). The first two sites are located near the metropolitan region of Rio de Janeiro city, Brazil. Atomic absorption spectroscopy (AAS) showed a significant difference $(\mathrm{P}<0.05)$ for zinc concentration in the hepatopancreas from organisms collected at the contaminated sites GB $(210 \pm 20 \mu \mathrm{g} / \mathrm{g}$ dry weight $)$ and SB $(181 \pm 16$ $\mu \mathrm{g} / \mathrm{g}$ dry weight) compared to the non-contaminated site RB (76 \pm 14 $\mu \mathrm{g} / \mathrm{g}$ dry weight). Phosphate granules isolated from hepatopancreatic tissue were studied by electron diffraction (ED), energy dispersive Xray analysis (EDX) and electron spectroscopic imaging (ESI). ED of granules presented no diffraction spots, indicating that these structures are in an amorphous state, while EDX of granules isolated from a contaminated area contained $\mathrm{P}, \mathrm{Ca}$ and $\mathrm{Zn}$. $\mathrm{Mg}, \mathrm{Cl}$ and $\mathrm{Fe}$ were also found in some of the spectra. ESI showed that $\mathrm{O}, \mathrm{P}$ and $\mathrm{Ca}$ were colocalized in the mineralized layers of most granules observed. The correlation between the results obtained by AAS and those obtained by microanalytical techniques suggests that the hepatopancreatic granules of $U$. cordatus may be related to the phenomenon of heavy metal retention.

The crustacean decapod Ucides cordatus is a crab of high ecologic and economic importance in forests and is an important organism associated with biogeochemical cycles of several elements in mangrove ecosystems. The species $U$. cordatus is widely distributed from the south of Florida (United
Key words

- Phosphate granules

- Hepatopancreas

- Zinc

- Energy dispersive X-ray analysis

- Atomic absorption spectroscopy

- Electron spectroscopic imaging
States of America) to the northern region of Santa Catarina State (Brazil). This organism is a source of proteins for several human communities $(1,2)$. In Rio de Janeiro State (southeastern Brazilian region), U. cordatus has been collected from three bays with different levels of metal pollution: Ribeira Bay 
(RB), located near the city of Angra dos Reis, for which no metal pollution or industrial activity has been reported, Sepetiba Bay (SB), characterized by heavy metal (mainly zinc and cadmium) contamination, and Guanabara Bay (GB), characterized as being impacted by effluents (including heavy metals) generated by the domestic and industrial park of the metropolitan region of Rio de Janeiro (3). The ranges of zinc concentrations $(\mu \mathrm{g} / \mathrm{g})$ in superficial bottom sediments (fraction $<0.75 \mu \mathrm{m}$ ) reported in the literature are: $50-470$ for GB (4), $184-938$ for SB (5) and 8-83 for RB (6). Heavy metal pollution may have deleterious effects on aquatic organisms because of their persistence and potential accumulation in biota (7). Along evolution, aquatic organisms developed mechanisms of sequestration, transport and excretion of metals; among them is the incorporation of metals into insoluble granules (8-11). Amorphous phosphate granules are intra- and extracellular granules, commonly surrounded by a membrane, with diameters ranging from 0.5 to $5 \mu \mathrm{m}$ and composed of concentric layers of an organic matrix associated with minerals $(12,13)$. They are generally developed in organs that have digestive, storage or excretory (detoxificatory) functions such as the hepatopancreas and cecum in crustaceans, digestive gland, midgut and kidney in mollusks, and Malpighian tubules in insects. In invertebrates, different types of granules have been described and characterized as carbonated, oxalated, sulfated, and phosphated structures that present high affinity for cations $(9,14,15)$.

It has been shown that the hepatopancreatic granules of Helix aspersa and Carcinus maenas consist predominantly of pyrophosphate and orthophosphate anions respectively, with calcium and magnesium as cations. The crab accumulates metals of group "a" such as magnesium and calcium $(11,16)$. It is believed that the incorporation of $\mathrm{Mg}^{2+}$ into the calcium pyrophosphate lattice may account for the amorphous state of the gran- ules, permitting the incorporation of other cations into the structure $(11,16)$.

In the present study we compared the zinc concentration in hepatopancreatic tissue of $U$. cordatus between a group of organisms collected from contaminated (GB and $\mathrm{SB})$ and non-contaminated (RB) areas by atomic absorption spectroscopy (AAS). Using energy dispersive X-ray analysis (EDX) we detected the principal elements of the hepatopancreatic granules. Elemental maps of oxygen, phosphorus and calcium were obtained from ultrathin sections of isolated granules by electron spectroscopic imaging (ESI).

$U$. cordatus specimens were sacrificed by mechanical lesion of the supra-esophageal ganglia and the hepatopancreatic tissue was dissected. For determination of zinc concentration in tissue, ten crabs were collected from each contaminated (SB, GB) and non-contaminated (RB) area. Each sample was dried for $96 \mathrm{~h}$ at $70^{\circ} \mathrm{C}$ until constant dry weight and then ashed for $48 \mathrm{~h}$ at $400^{\circ} \mathrm{C}$. Samples were digested with pure $\mathrm{HNO}_{3}, \mathrm{HCl}$ and $\mathrm{H}_{2} \mathrm{O}_{2}$ and resuspended in 10 $\mathrm{ml} 0.1 \mathrm{M} \mathrm{HCl}$. Zinc concentrations were determined by AAS (Varian AA-1475, Springvale, Australia). For each collection site the samples were processed in triplicate. The results are reported as $\mu \mathrm{g} \mathrm{Zn} / \mathrm{g}$ hepatopancreas dry weight. One-way ANOVA followed by the multiple comparison Tukey test was performed to compare the results of zinc concentration. For the analytical electron microscopy studies, isolated granules were obtained by chemical digestion of a hepatopancreas homogenate with $20 \%$ $\mathrm{NaOCl}$ in distilled water. The homogenate was centrifuged at $1500 \mathrm{~g}$ for $15 \mathrm{~min}$. After repeating digestion and elution several times, a clean pellet was obtained and rinsed with distilled water to remove $\mathrm{NaOCl}$. A drop rich in isolated granules was deposited on a formvar-covered copper grid and air-dried. Another part of the purified pellet was dried and embedded in Epon resin. Ultrathin sec- 
tions $(\cong 40 \mathrm{~nm})$ were obtained with an ultramicrotome (model RMC XT 6000-XL, Research and Manufacturing Co., Inc., Tucson, AZ, USA) with a diamond knife and collected on copper grids. The isolated granules were studied by X-ray microanalysis with a JEOL 2000FX transmission electron microscope equipped with a Tracor Nothern analytical system. ESI was performed with a Zeiss CEM 902 transmission electron microscope with an in column Castaing-Henry spectrometer (17).

Organisms collected at the contaminated sites $(\mathrm{GB}=210 \pm 20 \mu \mathrm{g} / \mathrm{g}$ and $\mathrm{SB}=181 \pm 16$ $\mu \mathrm{g} / \mathrm{g}$ ) showed significantly higher zinc concentrations in the hepatopancreas (one-way ANOVA, Tukey test, $\mathrm{P}<0.05)$ than the organisms collected at the non-contaminated site $(\mathrm{RB}=76 \pm 14 \mu \mathrm{g} / \mathrm{g})$ (Figure 1). Mineral granules were found to be amorphous as no defined rings were observed by electron diffraction (ED) (data not shown). EDX showed characteristic peaks of $\mathrm{Mg}, \mathrm{P}, \mathrm{Cl}, \mathrm{Ca}$, and $\mathrm{Zn}$ in purified granules from an organism collected in GB (Figure 2a). The spectrum indicates that the granule is composed of a phosphate matrix. Note that Zn occurs in significant amounts in these structures. ESI showed that $\mathrm{O}$ and $\mathrm{P}$ are colocalized in the most mineralized layers (Figure 2b,c), indicating that the granules are composed of a phosphate matrix in an amorphous state, also containing $\mathrm{Ca}$ (Figure $2 \mathrm{~d}$ ). However, as indicated by the $\mathrm{Ca}$ image, different levels of calcification may be present in different rings of the same granule because the Ca content is not completely colocalized with $\mathrm{O}$ and $\mathrm{P}$ (see arrow in Figure 2d).

The regulation of the internal concentrations of trace metals in crustaceans occurs by several pathways, e.g., the mechanisms to excrete sufficient quantities of metals involving active transmembrane transport, inducible synthesis of proteins (metallothioneins and other proteins) and incorporation of metals into insoluble granules $(8,9)$. In decapod crustaceans, the hepatopancreatic tissue is involved in ion and nutrient storage, synthesis of several substances, and accumulation and elimination of heavy metals $(8,11)$.

The significantly higher $(\mathrm{P}<0.05)$ hepato-

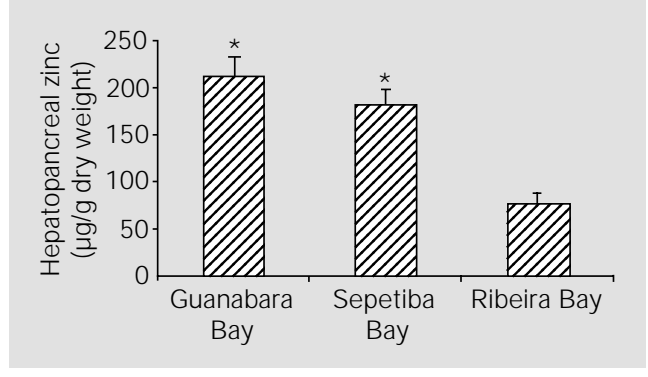

Figure 1 - Zinc concentration in the hepatopancreas of U. cordatus crabs from the contaminated areas of Guanabara Bay and Sepetiba Bay, and from a noncontaminated area of Ribeira Bay. Data are reported as means \pm SD for 10 crabs from each area. The hepatopancreatic zinc concentration found for the contaminated areas was significantly higher $\left({ }^{*} \mathrm{P}<0.05\right)$ compared to the control area (Tukey test).

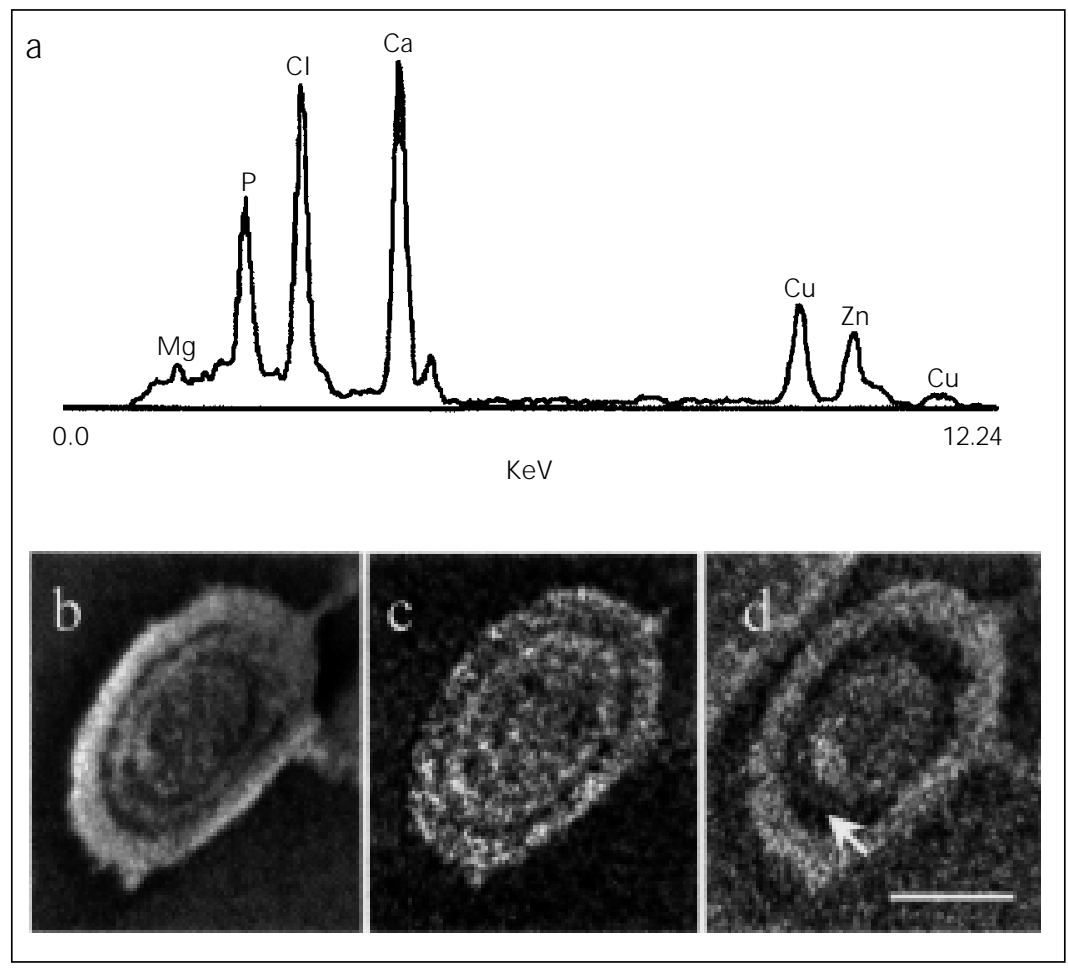

Figure 2 - a, X-Ray microanalysis spectrum of a typical hepatopancreatic granule isolated from a crab collected in the contaminated area of Guanabara Bay. Note the presence of magnesium, phosphorus and calcium, typical of phosphate intracellular granules, and zinc. Chlorine is also present, but it could be from $\mathrm{NaOCl}$ used for digestion. Oxygen is not detectable in the spectrum because of the beryllium window of the detector. Copper peaks come from the electron microscope grid. b, Electron spectroscopic image (ESI) of oxygen in a granule from a contaminated region. White rings correspond to higher contents of the element inside the structure. Section thickness, $\cong 40 \mathrm{~nm}$. c, ESI of phosphorus in the same granule showing that phosphorus and oxygen (see previous figure) are colocalized inside the structure. d, ESI of calcium inside the same granule as in the previous two figures. The arrow shows a region where the calcium content is very low as compared to oxygen and phosphorus. Bar $=0.5 \mu \mathrm{m}$. 
pancreas $\mathrm{Zn}$ content in organisms from the two contaminated regions (GB and SB) compared with that from the non-contaminated one (RB) indicates that the hepatopancreas may act as a storage site tissue when $\mathrm{Zn}$ is present in high concentrations in the environment, as observed in the contaminated sites.

Bryan and Langstom (18) suggested that decapod crustaceans can restrict $\mathrm{Zn}$ uptake to maintain more or less constant body loads independent of environmental concentrations. This was also shown by Pedersen and Lundebye (19) when studying metallothionein and stress protein levels in the midgut glands of the shore crab Carcinus maenas. On the other hand, Simmons et al. (20) concluded that metals from the food may be taken into the phosphate granules of Carcinus maenas. In this way, an extensive metal analysis in both sediments and hepatopancreas, or in vitro experiments are needed to determine if $U$. cordatus regulates $\mathrm{Zn}$ concentrations in the hepatopancreas.

In the present study we detected zinc in amorphous phosphate granules. The basic elemental composition of the granules was $\mathrm{O}, \mathrm{Mg}, \mathrm{P}$, and $\mathrm{Ca}$. When the amorphous material is complexed with a divalent cation it may stay in a noncrystallized state, with the cation acting as inhibitor of crystallization $(15,21)$; as a consequence, because of their solubility, these structures could be used to determine the bioavailability of heavy metals in the environment (20). The $\mathrm{Cl}$ peak seen in the spectrum (Figure 2a) is probably due to its $\mathrm{NaOCl}$ content used during organic digestion. The $\mathrm{O}, \mathrm{P}$, and $\mathrm{Ca}$ maps shown here (Figure 2b,c,d) indicate that cations other than Ca may compete for the same lattice sites inside the amorphous phosphate structure of the granule, because one of the rings of the calcium map of the granule in Figure $2 \mathrm{~d}$ presents a small calcium content when compared to the $\mathrm{O}$ and $\mathrm{P}$ images of the corresponding ring. The presence of $\mathrm{Zn}$ in the structure could be responsible for a decrease in Ca concentration. This fact is in agreement with Simkiss and Taylor (11) who showed that snails fed on a diet rich in $\mathrm{Zn}$ presented higher $\mathrm{Zn}$ and lower calcium levels inside the granules as compared with those fed a normal diet.

The association between data obtained by AAS, EDX and ESI suggests that amorphous phosphate granules can contribute to the process of heavy metal accumulation, explaining in part the high concentration of $\mathrm{Zn}$ detected in hepatopancreatic tissue from contaminated specimens. In particular, ESI may further contribute to the understanding of ion transfer between the solid phase of the granule and the solution.

\section{References}

1. Alcântara-Filho $P$ (1978). Contribuição ao estudo da biologia e ecologia do caranguejo-uçá, Ucides cordatus (Linnaeus, 1763) (Crustacea, Decapoda, Brachyura), no manguezal do Rio Ceará (Brasil). Arquivos de Ciências do Mar, 18: 1-41.

2. Ostrensky A, Sternhain US, Brun E, Wegbecher FX \& Pestana D (1995). Technical and economic feasibility analysis of the culture of the land crab Ucides cordatus (Linnaeus, 1763) in Paraná coast, Brasil. Arquivos de Biologia e Tecnologia, 38: 939-947.

3. Feema (1987). Qualidade das Águas do Estado do Rio de J aneiro 1980/1986. Feema (Fundação Estadual de Engenharia do Meio Ambiente), Vol. 1. Março de 1987. DIPLAM-DEP, Rio de J aneiro.

4. Caçônia AJ (1984). Distribuição do cobre, chumbo e zinco em sedimentos superficiais da área norte da Baía de Guanabara, Rio de J aneiro. Master's thesis, Departamento de Geoquímica, Universidade Federal Fluminense.

5. Fizman M, Pfeiffer WC \& Lacerda LD (1984). Comparison of methods used for extraction and geochemical distribution of heavy metals in bottom sediments from Sepetiba Bay, RJ . Environmental Technology Letters, 5: 567-575.

6. Lacerda LD, Pfeiffer WC \& Fizman M (1987). Heavy metal distribution, availabil- ity and fate in Sepetiba Bay, SE, Brazil. Science of the Total Environment, 65: 163-173.

7. Amiard J C, Amiard-Triquet C, Berthete $B$ \& Metayer C (1987). Comparative study of the patterns of bioaccumulation of essential $(\mathrm{Cu}, \mathrm{Zn})$ and non-essential $(\mathrm{Cd}, \mathrm{Pb})$ trace metals in various estuarine and coastal organisms. J ournal of Experimental Marine Biology, 106: 73-89.

8. Phillips DJ H \& Rainbow PS (1989). Strategies of trace metal sequestration in aquatic organisms. Marine Environmental Research, 28: 207-210.

9. Brown BE (1982). The form and function of metal-containing "granules" in inverte- 
brate tissues. Biological Reviews, 57: 621667.

10. George SG (1982). Subcellular accumulation and detoxification of metals in aquatic animals. In: Vernberg WD, Calabrese A, Thurberg FP \& Vernberg FJ (Editors), Physiological Mechanisms of Marine Pollutant Toxicity. Academic Press, New York, 3-52.

11. Simkiss K \& Taylor MG (1994). Calcium magnesium phosphate granules: atomistic simulations explaining cell death. J ournal of Experimental Biology, 190: 131-139.

12. Chen C-H, Greenawalt J W \& Lehninger AL (1974). Biochemical and ultrastructural aspects of $\mathrm{Ca}^{2+}$ transport by mitochondria of the hepatopancreas of the blue crab Callinectes sapidus. J ournal of Cell Biology, 61: 301-315.

13. Silverman $H$, Sibley $D \&$ Steffens $W L$ (1988). Calmodulin-like calcium binding protein identified in calcium-rich mineral deposits from freshwater mussel gills.
J ournal of Experimental Zoology, 247: 227-231.

14. Martoja R \& Ballan-Dufrançais CB (1984). The ultrastructure of the digestive and excretory organs. In: King RC \& Akai $\mathrm{H}$ (Editors), Insect Ultrastructure II. Plenum Press, Cambridge, London, 199-267.

15. Simkiss K (1989). Structural and analytical studies on metal ion-containing granules. In: Mann S, Webb RJ \& Williams RJP (Editors), Biomineralization, Chemical and Biochemical Perspectives. VCH Verlagsgesellschaft, Weinheim, Germany, 427460.

16. Lee AP, Klinowski J, Taylor M G \& Simkiss K (1995). X-ray diffraction and multinuclear solid-state NMR studies of hepatopancreal granules from Helix aspersa and Carcinus maenas. Proceedings of the Royal Society of London. B, Biological Sciences, 261: 263-270.

17. Bauer R (1988). Electron spectroscopic imaging: an advanced technique for imag- ing and analysis in transmission electron microscopy. Methods in Microbiology, 20: 113-146.

18. Bryan GW \& Langstom WJ (1992). Bioavailability, accumulation and effects of heavy metals in sediments with special reference to United Kingdom estuaries: a review. Environmental Pollution, 76: 89131.

19. Pedersen SN \& Lundebye AK (1996). Metallothionein and stress protein levels in shore crabs (Carcinus maenas) along a trace metal gradient in the Fall. Marine Environmental Research, 42: 241-246.

20. Simmons J , Simkiss K, Taylor M G \& J arvis KE (1996). Crab biominerals as environmental monitors. Bulletin de I'Institut Océanographique, 14 (No. spécial): 225231.

21. Mason AZ \& Simkiss K (1982). Sites of mineral deposition in metal-accumulating cells. Experimental Cell Research, 139: 383-391. 